
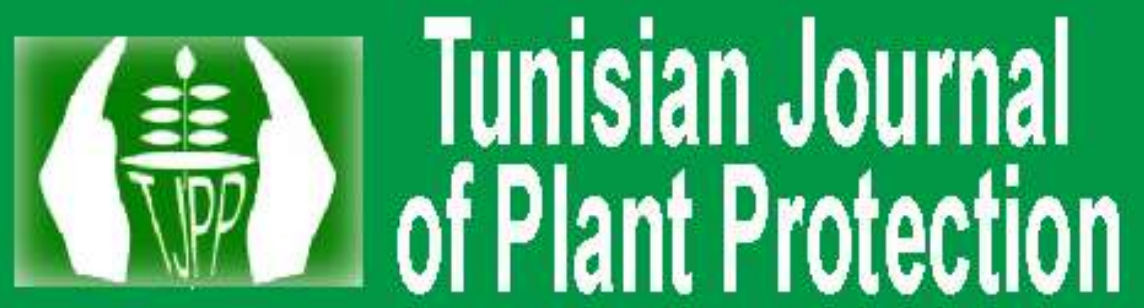

Volume 16

Number 2

December 2021

A Tunisian Holf-Youry Joumal of Plant Healh Sciences (TJP)

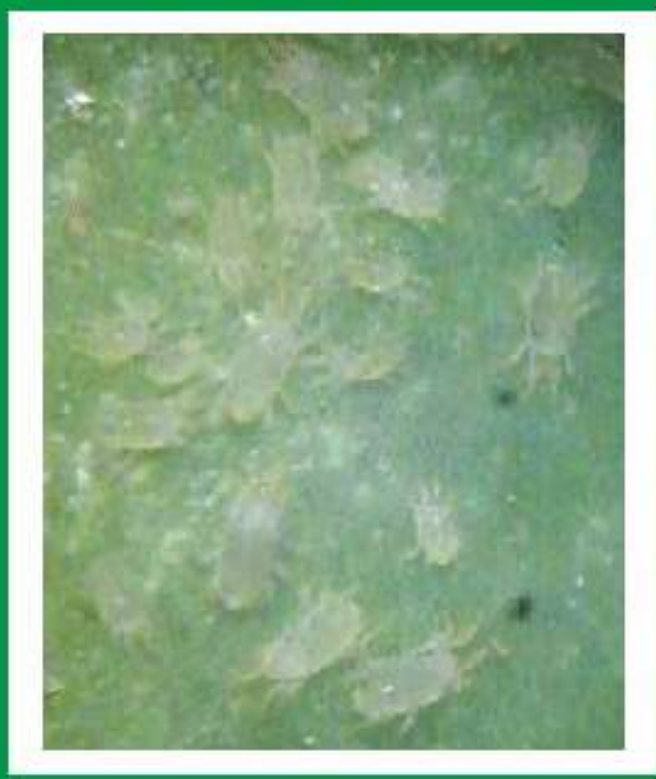

http:/www.tjpp.tn

eISSN 2490-4368 pISSN 1737-5436 


\title{
Tunisian Journal of Plant Protection \\ http://www.tipp.tn
}

\author{
https://doi.org/10.52543/tipp
}

\section{Volume 16, No 2, December 2021}

\section{Contents}

\section{VIROLOGY}

19- Prevalence and genetic diversity of grapevine virus D in Tunisia. Selmi, I., Elbeaino, T., Arezki, L., El Air, M., Digiaro, M., and Mahfoudhi, N. (Algeria/Italy/Tunisia)

https://doi.org/10.52543/tipp.16.2.1

\section{ENTOMOLOGY}

29- Evaluation under laboratory conditions of the efficacy of four extracts of spontaneous plants from the Mzab Valley (Algeria) against the date palm mite (Oligonychus afrasiaticus). Babaz, Y., Guezoul, O., and Bouras, N. (Algeria) https://doi.org/10.52543/tipp.16.2.2

Photo of the cover page: Oligonychus afrasiaticus (Courtesy Younes Babaz) 


\section{Acknowledgement of Reviewers}

Tunisian Journal of Plant Protection (TJPP) gratefully appreciates the volunteer help of reviewers which evaluate, with care and competence, papers proposed for publication in the 2 Issues of the $16^{\text {th }}$ Volume, 2021. They are listed below in recognition of their contribution.

Abu Irmaileh, Barakat University of Jordan, Jordan

Al-Jboory Ibrahim, CA, Univ. Baghdad, Iraq

Al-khateeb, Tamara, Ministry of Agriculture, Baghdad, Iraq

Allagui, Med Béchir, INRAT, Univ. Carthage, Tunisia

Bayaa, Bassam, Univ.Aleppo/ICARDA, Syria

Benazoun, Abdessalam, IAV Hassenll-CHA, Agadir, Morocco

Ben Chaaban, Samah, CRRAOD, Univ. Gafsa, Tunisia

Boulahia-Khedher Synda, INAT, Univ. Carthage, Tunis, Tunisia

Braham, Mohamed, CRRHABChM, Univ. Sousse, Chott-Mariem, Tunisia

Chaabane-Boujnah, Hanène, INAT, Univ. Carthage, Tunis, Tunisia

Chaieb, Ikbal, CRRHABChM, Univ. Sousse, Tunisia

Chermiti, Brahim, ISAChM, Univ. Sousse, Chott-Mariem, Tunisia

Choueiri, Elia, LARI, Lebanon

El-Heneidy, Ahmed, PPRI, Egypt

Fakhfakh, Hatem, FSB, Univ. Carthage, Tunisia

Glida, Habiba, ESAK, University of Jemdouba, Le Kef, Tunisia

Haouala, Rabia, ISAChM, Univ. Sousse, Chott-Mariem, Tunisia

Jaddou, Marwan, IPM Consultant, Jordan

Laamari, Malik, ISAV, Univ. Batna 1, Algeria

Makkouk, Khaled, CNRS, Beirut, Lebanon

Mazih, Ahmed, IAV Hassan II, Agadir, Morocco

Medjdoub-Bensaad, Ferroudja, FSBSA, Univ. Mouloud Mammeri, Tizi-Ouzou, Algeria

Mekki, Mounir, ISAChM, Univ. Sousse, Chott-Mariem, Tunisia

Rhaiem, Azza, BNG, Tunis, Tunisia

Soltani, Noureddine, FS, Univ. Badji Mokhtar, Annaba, Algeria

Zermane, Nadjia, ENSA, Algiers, Algeria

Special thanks go to (1) Nasraoui, Bouzid, INAT, Univ. Carthage, Tunis, Tunisia, and (2) Michel Ferry, Phoenix Research Station, Elche, Spain, for writing for TJPP the Guest Editorials in respectively Issues No. 1 and No. 2 of the Volume 16 (2021). 


\section{Guest Editorial}

\section{Smartmania and pest control, especially related to red palm weevil}

The use of the term "smart" associated with technologies in a large number of fields, including in pest control, is rather new but its use is more and more frequent in scientific papers but, moreover, in commercial propaganda. A search in Google scholar on the keys words "smart" and "red palm weevil" (RPW) shows that form the last 20 years, the number of occurrences has been multiplied on average by 3 each five years since 2020. No occurrence before that date.

The analysis of the scientific papers and commercial propaganda shows that the use of this term is associated with different new or not so new scientific and technological concepts and breakthroughs in different areas: biotechnology, satellite and UAV imagery, machine learning, microelectronics, internet of things (IoT), etc.

The progress in these areas has been spectacular and fascinating but, too often, this fascination has led to such infatuation for "smart" solutions that other approaches (in other disciplines including socio-economy) have been increasingly considered to be less promising and even outdated. Regarding
$R P W$, this "smartmania" has been generally excessive as the demonstration of the real potential and efficiency of "smart" solutions in comparison with previous proposals remain still largely to be demonstrated.

Frequently, new "smart" solutions have been intensively hyped as magic bullet solutions offering incredible efficiency when their promoters do not even present any field data to defend their claim. In some cases, scientific papers have been published but most of them have corresponded to preliminary results or not to field conditions. When experimentations have been done in field conditions, protocols have been sometimes questionable. It is quite normal as testing a technology to control this pest, in real field conditions, is very challenging, especially because of the clustered spreading behaviour of the $R P W$ and of the heavy constraints that represents experimenting with a quarantine pest. More surprising is the confusion that is present in several papers where the lack of statistic significant difference between treatments is interpreted as the proof of their equivalence. 
The inadequacy of some proposals of new "smart" solution is also linked to the fact that startups or laboratories that are designing them are very specialized and have not in their team experts with good field experience in the control of $R P W$. In addition, as a lot of hype accompanies the development of each new "smart" solution, the vision that this pest can be controlled by a unique technological solution become predominant, when, against RPW as for other pests, it is strongly established for a long time that the strategic approach must be based on IPM. Moreover, as $R P W$ is a quarantine pest, this strategy must be first applied in the framework of an area-wide management and, secondly, conceived, for imperative sustainability reasons, to obtain as quickly as possible the strong decrease of RPW population.

There is no doubt that "smart" technologies could contribute on various aspects to improve the efficiency of the $R P W$ integrated control but this efficiency, as for any other type of technology should be seriously established before being promoted. Propositions of not mature or, even, not efficient new "smart" solutions lead to deception and to increasing scepticism.

In addition to the real field efficiency of new "smart" solutions, another fundamental issue must be considered in relation to their adequacy with the socio-economic context. Is their cost affordable and are their conditions of use (ease of use, time consuming) acceptable for the palms owners and especially the farmers? These questions lead to complementary ones: for whom are developed these "smart" solutions? Are they developed to be appropriable and used by small family farming systems or only by large commercial companies, these two very different types of farming systems existing in the oasis? In addition, the situation is quite difference between countries: in some of them, the control of the RPW is totally financed and implemented by the State and its agencies; in other, it is entirely or nearly realized and at the expense of the farmers. Are the proposed "smart" solutions adapted to these two completely different situations?

It is very important to answer to these questions before designing or promoting a new "smart" solution, as the successful control of this pest requires imperatively, as previously highlighted, an area-wide management strategy and a strong and general decrease of the RPW population, which means that $R P W$ control programme must concern all the palms in the infested area and consequently all the palms owners.

Finally, when promoting a "smart" approach or solution, we should be careful not to consider the previous ones as no "smart" ones or as outdated. At the contrary, assessment of a new "smart" approach or solution must be established by comparing carefully with the existing ones, on all aspects, including in the socio-economic field. In the same way, we must be careful to prevent the development of the idea that, without new "smart" technologies, the RPW control is doomed to fail. The reasons why RPW control has failed till now have been well established. The main reasons are not 
technical but, of course, new "smart" solutions, after a complete and serious field assessment, could play an important role to facilitate the implementation of the existing RPW control plans.

\section{Michel Ferry \\ Phoenix Research Station \\ Elche, Spain}




\title{
Prevalence and Genetic Diversity of Grapevine Virus D in Tunisia
}

Ilhem Selmi, Laboratoire de Protection des Végétaux LR16INRAT04, Institut National de la Recherche Agronomique de Tunisie, Université de Carthage, Rue Hedi Karray, 1004 ElMenzah, Tunis, Tunisia, Toufic Elbeaino, Istituto Agronomico Mediterraneo di Bari, Via Ceglie 9, 70100 Valenzano, Bari, Italy, Lehad Arezki, Laboratoire de Phytopathologie et Biologie Moléculaire, Ecole Nationale Supérieure d'Agronomie, Rue Hacen Badi, Belfort, El Harrach, 16000 Alger, Algeria, Manel El Air, Laboratoire de Protection des Végétaux LR16INRAT04, Institut National de la Recherche Agronomique de Tunisie, Université de Carthage, Rue Hedi Karray, 1004 ElMenzah, Tunis, Tunisia, Michele Digiaro, Istituto Agronomico Mediterraneo di Bari, Via Ceglie 9, 70100 Valenzano, Bari, Italy, and Naima Mahfoudhi, Laboratoire de Protection des Végétaux LR16INRAT04, Institut National de la Recherche Agronomique de Tunisie, Université de Carthage, Rue Hedi Karray, 1004 ElMenzah, Tunis, Tunisia https://doi.org/10.52543/tipp.16.2.1

(Tunisia / Italy / Algeria)

\begin{abstract}
Selmi, I., Elbeaino, T., Arezki, L., El Air, M., Digiaro, M., and Mahfoudhi, N. 2021. Prevalence and genetic diversity of grapevine virus D in Tunisia. Tunisian Journal of Plant Protection 16 (2): 19-27.

The prevalence and the genetic diversity of grapevine virus D (GVD) isolates from rootstocks, wine and table grape varieties grown in Tunisia were studied. RT-PCR assays performed on the coat protein gene (CP) showed the presence of GVD in $31.5 \%$ of the 403 samples tested. The highest rate of infection was found in table grapes (56.5\%), followed by autochthonous table grapes $(24.1 \%)$, wine grapes $(20.8 \%)$ and rootstocks (12.5\%). Sequences and phylogenetic analyses of the partial CP genes of 14 GVD isolates showed nucleotide identities that ranged from $84 \%$ to $99 \%$. The Tunisian GVD-isolates segregated in 3 phylogenetic groups together with international isolates reported in GenBank. The present study extends our knowledge of the presence of GVD in Tunisian vines and on its genetic diversity, which is useful for developing broad-spectrum molecular diagnostics (RT-PCR) capable of detecting the different isolates infecting vines.
\end{abstract}

Keywords: Grapevine, phylogenetic analysis, RT-PCR, sequences, vitiviruses

Rugose wood (RW) represents one of the most important grafttransmissible diseases affecting Vitis species worldwide (Martelli and Boudon-

Corresponding author: Naima Mahfoudhi

Email: nmahfoudhi@yahoo.fr

Accepted for publication 25 December 2021

Tunisian Journal of Plant Protection
Padieu 2006). Four disorders distinguishable by grafting onto woody indicators plants are associated with this complex disease: stem pitting on Vitis rupestris, stem grooving on Kober $5 \mathrm{BB}$, corky bark and stem grooving on LN33 (Martelli 2014). Some of these syndromes are associated with vitiviruses of the family Betaflexiviridae. Grapevine virus A (GVA) is associated with stem grooving 
on Kober 5BB (Digiaro et al. 1994; Garau et al. 1994; Chevalier et al. 1995), grapevine virus $B(G V B)$ is recognized as the causal agent of corky bark (Bonavia et al. 1996) and grapevine virus $\mathrm{D}$ (GVD) is associated to the growth reduction of Freedom rootstock (AbouGhanem et al. 1997). Additionally, these vitiviruses are frequently detected in coinfection with grapevine leafroll viruses, resulting in synergetic interactions that can lead to lethal effects in several scion and rootstocks combinations (Rowhani et al. 2018). In recent years, several new vitiviruses have been isolated from grapevine (GVE, GVF, GVG, GVH, GVI, GVJ, GVL and GVM) but their potential pathogenic role in RW disease is still unknown (Nakaune et al. 2008; Al Rwahnih et al. 2012; Blouin et al. 2018a and 2018b; Candresse et al. 2018; Diaz-Lara et al. 2018; Alabi et al. 2019; Debat et al. 2019).

GVD was detected for the first time in south Italy in vines with corky rugose wood symptoms (AbouGhanemet al. 1997). The virus is serologically distantly related to GVA and GVB (Choueiri et al. 1997), but it closely resembles GVA in biological behaviour, particle size and morphology, cytopathology, dsRNA pattern, size of RNA and organization of the 3 ' terminal genomic region. Virions are filamentous particles of about $825 \times 12 \mathrm{~nm}$. The presence of GVD was assessed in Tunisian vineyards in a previous study (Mahfoudhi et al. 2014), but no information was provided about the genetic diversity of its isolates. Therefore, a new investigation has been carried out to determine the genetic population structure of GVD isolates in Tunisia.

\section{MATERIALS AND METHODS Field surveys and sample collection.}

Field surveys were carried out in the main Tunisian grapevine growing areas to assess the GVD occurrence in the vineyards. Mature canes were collected from a total of 403 vine samples, including 141 vines of autochthonous varieties maintained in a germplasm collection plot established at INRAT (Tunis), 115 samples of wine and 115 of table grape varieties from commercial vineyards, and 32 rootstocks from mother tree plots. The number of samples collected was relative to the importance, type and origin of cultivars in Tunisia. Mature canes were randomly collected in winter and stored at $4^{\circ} \mathrm{C}$, until laboratory testing.

\section{Total nucleic acids extraction.}

Total nucleic acids (TNA) were extracted according to Foissac et al. (2001). Two hundred $\mathrm{mg}$ of phloem tissues (cortical scrapings) from each sample were ground in $1 \mathrm{ml}$ of extraction buffer $(4 \mathrm{M}$ guanidine thiocyanate, $0.2 \mathrm{M}$ Sodium acetate $\mathrm{pH}$ 5.2, $25 \mathrm{mM}$ EDTA, $1.0 \mathrm{M}$ potassium acetate $\mathrm{pH} 5.0$ and $2.5 \% \mathrm{w} / \mathrm{v}$ PVP-40) and mixed with $2 \%$ sodium metabisulfite as antioxidant. The mixture was transferred into an Eppendorf tube containing $100 \mu \mathrm{l} \quad \mathrm{N}$-Lauroylsarcosine sodium salt (NLS $10 \%$ ), incubated at $70^{\circ} \mathrm{C}$ for $10 \mathrm{~min}$, and then placed on ice for 5 min. After centrifugation at $10,000 \mathrm{~g}$ for $10 \mathrm{~min}, 300 \mu \mathrm{l}$ of supernatant were transferred to an Eppendorf tube to which $150 \mu \mathrm{l}$ absolute ethanol, $300 \mu \mathrm{l}$ sodium iodide $(6 \mathrm{M})$ and $50 \mu \mathrm{l}$ of silicon dioxide $\left(\mathrm{SiO}_{2}\right)$ were added. The mixture was stirred for $30 \mathrm{~min}$ at room temperature and then centrifuged at 5,000 $\mathrm{g}$ for $1 \mathrm{~min}$. After washing with $500 \mu \mathrm{l}$ of washing buffer (50\% STE 1X, 50\% absolute ethanol), the pellet was re-suspended in $120 \mu \mathrm{l}$ of sterile distilled water, incubated for $3 \mathrm{~min}$ at 70 ${ }^{\circ} \mathrm{C}$ and then centrifuged at $10,000 \mathrm{~g}$ for 3 $\min$. The supernatant containing the total 
nucleic acids was transferred to a new Eppendorf tube and stored at $-20^{\circ} \mathrm{C}$.

Reverse transcription and Polymerase chain reaction ( $R T-P C R)$.

Five hundred ng of TNAs were mixed with $0.5 \mu \mathrm{g}$ random primers and 1.5 $\mu \mathrm{l}$ of sterile water and denatured at $95^{\circ} \mathrm{C}$ for $5 \mathrm{~min}$. Reverse transcription was performed for $1 \mathrm{~h}$ at $39^{\circ} \mathrm{C}$ using 200 units of Moloney Murine Leukemia Virus (Invitrogen Corporation, USA), $4 \mu \mathrm{l}$ buffer (5x First-strand Fs), $2 \mu 1$ DTT (0.1 M) and $0.5 \mu \mathrm{ldNTPs}(10 \mathrm{mM})$ and adjusted to a final volume of $20 \mu \mathrm{l}$ with sterile distilled water. A volume of $2.5 \mu \mathrm{l}$ of the synthetized cDNA was submitted to PCR amplification using a mixture containing $2.5 \mu \mathrm{l} 10 \mathrm{X}$ Taq polymerase buffer, $1 \mu \mathrm{l}$ $\mathrm{MgCl}_{2}$ (50 mM), $1 \mu \mathrm{l}$ dNTPs (10 mM), 0.5 $\mu \mathrm{l}$ of each primer $(20 \mu \mathrm{M})$ [GVD-CP7V (5'-CTTAGGACGCTCTTCGGGTACA3') and GVD-CP471C (5'CTGCTCTCCAACCGACGACT-3')]

(AbouGhanem et al. 1997) and $0.25 \mu \mathrm{l} \mathrm{Taq}$ polymerase $(5 \mathrm{u} / \mu \mathrm{l}) \quad$ (Invitrogen Corporation, CA, USA), and adjusted to a final volume of $25 \mu \mathrm{l}$ with sterile distilled water. PCR reactions consisted of one cycle at $94^{\circ} \mathrm{C}$ for $5 \mathrm{~min}$, followed by 35 cycles of denaturation at $94^{\circ} \mathrm{C}$ for $35 \mathrm{sec}$, annealing at $54^{\circ} \mathrm{C}$ for $45 \mathrm{sec}$ and elongation at $72^{\circ} \mathrm{C}$ for $1 \mathrm{~min}$, and a final extension step at $72^{\circ} \mathrm{C}$ for $7 \mathrm{~min}$. The PCR products were analyzed by electrophoresis in $1.2 \%$ agarose gel in $1 \mathrm{X}$ TBE buffer and visualized under UV light after staining with ethidium bromide.

\section{Sequencing and sequence analysis.}

Fourteen Tunisian GVD isolates from the major cultivated table and wine grape cultivars as well as from autochthonous grapevines from different regions were chosen for the genetic diversity study of this virus. RT-PCR amplicons of all selected isolates were ligated into Strataclone ${ }^{\mathrm{TM}}$ PCR cloning vector PSCA (Stratagene, California, USA), sub-cloned into Escherichia coli DH5 $\alpha$ cells and sequenced.

Sequences of Tunisian GVDisolates obtained from this study were compared to those reported in GenBank. The phylogenetic tree was constructed using the Neighbour-joining (NJ) method (with 1000 bootstrap replicates) under MEGA7 software (Kumar et al. 2016), and the inter- and intra-group genomic identities were calculated.

\section{RESULTS}

\section{Detection of GVD in Tunisian vineyards.}

RT-PCR assays successfully amplified the expected 474 bp product from 127 out of 403 tested samples (31.5\%). The highest GVD infection rates were detected in table grapes $(56.5 \%)$ and wine grapes $(20.8 \%)$ collected from commercial vineyards, while a significant lower level of GVD-infection was found in rootstock samples collected from mother plant plots $(12.5 \%)$. The autochthonous vines grown in the collection plots, which were dominantly table grapes, showed a level of GVD-infection of $24.1 \%$.

Among table grapes, the highest infection rates were observed in cvs. Italia and Rich Baba Sam (88.8\%), followed by cv. Dabouki (73.3\%), whereas, among wine grapes, in cvs. Alicante Boushet (25\%), Grenache and Carignan $(21.4 \%)$.

Out of 141 autochthonous vine samples tested, 34 were GVD-positive. Among these vines, significant difference in GVD infection rate was observed in samples coming from north of Tunisia (32.8\%) compared to those collected from the south $(15.5 \%)$. In the rootstocks, GVD was present in $30 \%$ of $1103 \mathrm{P}$ and $11.1 \%$ of $140 \mathrm{Ru}$, while no infection was detected in 110R. 


\section{Genetic diversity analysis.}

The partial CP sequences of 14 Tunisian GVD isolates obtained in this study from different infected Tunisian grapevine accessions (autochthonous, table and wine grape cultivars) were deposited into the European Nucleotide
Archive (ENA) database and assigned accession numbers (Table 1). The sequences were compared with each other and with those of GVD isolates present in the database to obtain more information on the genetic diversity of this virus in Tunisian vineyards.

Table 1. List and identifiers of the coat protein genes of grapevine virus D isolates sequenced and analyzed in this study

\begin{tabular}{c|c|c|c}
\hline Isolate & Cultivar & Origin & Accession number \\
\hline Tn4 & Carignan & Takelsa & LT908458 \\
Tn6 & Dabouki & Takelsa & LT908459 \\
Tn7 & Italia & Essaada & LT908460 \\
Tn8 & Italia & Essaada & LT908461 \\
Tn9 & Marsaoui* & Raf Raf & LT908462 \\
Tn10 & Asli* & Sfax & LT908463 \\
Tn11 & Testouri* & Djebba & LT908464 \\
Tn12 & Dabouki & Takelsa & LT908465 \\
Tn13 & Italia & Takelsa & LT908466 \\
Tn14 & Italia & Takelsa & LT908467 \\
Tn15 & Jerbi* & Degueche & LT908468 \\
TnM1 & Meski & Raf Raf & LT908457 \\
TnG5 & Rich Baba Sam & Bousalem & LT908454 \\
TnI-3 & Italia & Takelsa & LT908455 \\
TnI-5 & Italia & Takelsa & LT908456 \\
\hline
\end{tabular}

* Autochthonous varieties

Sequence analyses showed that the Tunisian isolates share nt identities comprised between $84 \%$ to $99 \%$ (Table 2). Isolates $\operatorname{Tn} 11, \operatorname{Tn} 12, \operatorname{Tn} 13, \operatorname{Tn} 15$ and TnI3 of the same cluster II-a shared $91 \%$ to $96 \%$ nt identities among them, except for the isolate Tn11 that shared $87 \%$ to 92\% identities (Table 2). Isolate $\mathrm{Tn} 4$ of Group II-b showed a high divergence from all the other Tunisian isolates, with nt identities ranging from $87 \%$ to $92 \%$ (Table 2). Isolates $\operatorname{TnG} 5, \operatorname{Tn} 6, \operatorname{Tn} 7, \operatorname{Tn} 8, \operatorname{Tn} 9$, Tn14 and TnI5 of the Group I-a showed $91 \%$ to $100 \%$ of nt identities. The two Tunisian isolates TnM1 and Tn10 of the Group II-c were distant from all other
Tunisian isolates and shared $97 \% \mathrm{nt}$ identity with each other. The clones TnI-3 and TnI- 5 obtained from the same isolate $\mathrm{TnI}$ showed $90 \%$ nt identity between them.

The "intra mean distance" revealed 94\% nt identity for Group II-a, 98\% for Group II-b, $94 \%$ for Group I-b, 95\% for Group I-a and 97\% for Group IIc. The "inter mean distance" between the Groups I and II ranged from $90 \%$ to $91 \%$ at nt level. The sole isolate BM-RM of the Group III showed a great divergence at nt level from the other two groups, with identity values varying between $83 \%$ and 84\% (Tables 3 and 4). 
Table 2. Matrix of nucleotide homologies among the CP sequences of 14 GVD Tunisian isolates

\begin{tabular}{l|c|c|c|c|c|c|c|c|c|c|c|c|c|c|c}
\hline Isolate & TnG5 & TnI3 & TnI5 & TnM1 & Tn4 & Tn6 & Tn7 & Tn8 & Tn9 & Tn10 & Tn11 & Tn12 & Tn13 & Tn14 & Tn15 \\
\hline TnG5 & 100 & & & & & & & & & & & & & & \\
TnI3 & 86 & 100 & & & & & & & & & & & & \\
TnI5 & 93 & 90 & 100 & & & & & & & & & & & \\
TnM1 & 87 & 89 & 91 & 100 & & & & & & & & & & & \\
Tn4 & 88 & 92 & 92 & 91 & 100 & & & & & & & & & & \\
Tn6 & 93 & 90 & 99 & 91 & 92 & 100 & & & & & & & & & \\
Tn7 & 94 & 90 & 98 & 91 & 92 & 99 & 100 & & & & & & & & \\
Tn8 & 91 & 89 & 95 & 87 & 89 & 95 & 95 & 100 & & & & & & & \\
Tn9 & 94 & 90 & 99 & 91 & 92 & 99 & 99 & 96 & 100 & & & & & & \\
Tn10 & 88 & 91 & 91 & 97 & 92 & 91 & 91 & 88 & 91 & 100 & & & & & \\
Tn11 & 84 & 88 & 88 & 87 & 87 & 87 & 87 & 86 & 87 & 87 & 100 & & & \\
Tn12 & 87 & 92 & 92 & 89 & 91 & 92 & 92 & 90 & 92 & 91 & 91 & 100 & & \\
Tn13 & 87 & 91 & 92 & 91 & 92 & 92 & 92 & 90 & 93 & 92 & 92 & 95 & 100 & & \\
Tn14 & 94 & 90 & 99 & 91 & 92 & 99 & 99 & 96 & 100 & 91 & 87 & 92 & 93 & 100 \\
Tn15 & 87 & 91 & 91 & 90 & 90 & 91 & 91 & 90 & 92 & 91 & 91 & 95 & 96 & 92 & 100 \\
\hline
\end{tabular}

Table 3. Intramean distance identity between different subgroups of GVD isolates

\begin{tabular}{|c|c|}
\hline I & $94 \%$ \\
II & $92 \%$ \\
I-a & $95 \%$ \\
I-b & $94 \%$ \\
II-a & $94 \%$ \\
II-c & $97 \%$ \\
II-b & $98 \%$ \\
\hline
\end{tabular}

Table 4. Intermean distance identity between different subgroups of GVD isolates

\begin{tabular}{c|c|c|c|c|c|c}
\hline Subgroup & I-a & I-b & II-a & II-c & II-b & III \\
\hline I-a & $100 \%$ & & & & & \\
I-b & $91 \%$ & $100 \%$ & & & & \\
II-a & $90 \%$ & $91 \%$ & $100 \%$ & & & \\
II-c & $90 \%$ & $90 \%$ & $90 \%$ & $100 \%$ & & \\
II-b & $91 \%$ & $91 \%$ & $91 \%$ & $89 \%$ & $100 \%$ & \\
III & $84 \%$ & $83 \%$ & $83 \%$ & $84 \%$ & $84 \%$ & $100 \%$ \\
\hline
\end{tabular}




\section{Phylogenetic analysis.}

The phylogenetic tree constructed on sequences of the Tunisian and GenBank isolates revealed three groups (GI-III) for GVD, with GI and GII further subdivided into $2(\mathrm{a}, \mathrm{b})$ and 3 subgroups (a-c), respectively (Fig. 1). Most of Tunisian isolates clustered into the Group I (TnG5, Tn6, Tn7, Tn8, Tn9, Tn14 and TnI5) and Group II (Tn11, Tn12, Tn13, Tn15, TnI3, Tn4, TnM1 and Tn10), in particular in the subgroups GI-a and GII-a, together with Italian isolates whose plant material is reported to be originated from Tunisia (Elbeaino et al. 2019). Interesting was the allocation of the Brazilian isolate RM-BR that was highly divergent and distant from all other GVDisolates.
Dissecting the allocations of Tunisian isolates within the phylogenetic tree, isolates from the table cultivars clustered into Group I-a (TnG5, Tn6, Tn7, Tn8, Tn14 and TnI5), II-a (Tn12, Tn13 and TnI3) and II-c (TnM1). In the same three subgroups of isolates clustered all the GVD isolates from autochthonous accessions: Tn9 (Group I-a), Tn11 and Tn15 (Group II-a) and Tn10 (Group II-c). $\mathrm{Tn} 4$ isolate of cv. Carignan was the sole Tunisian isolate to cluster into Group II-b. The two clones TnI3 and TnI5, from the same grapevine sample (TnI), clustered into Group II-a and Group I-a respectively, indicating a putative co-existence of mixture of GVD genetic variants in the same vine sample.

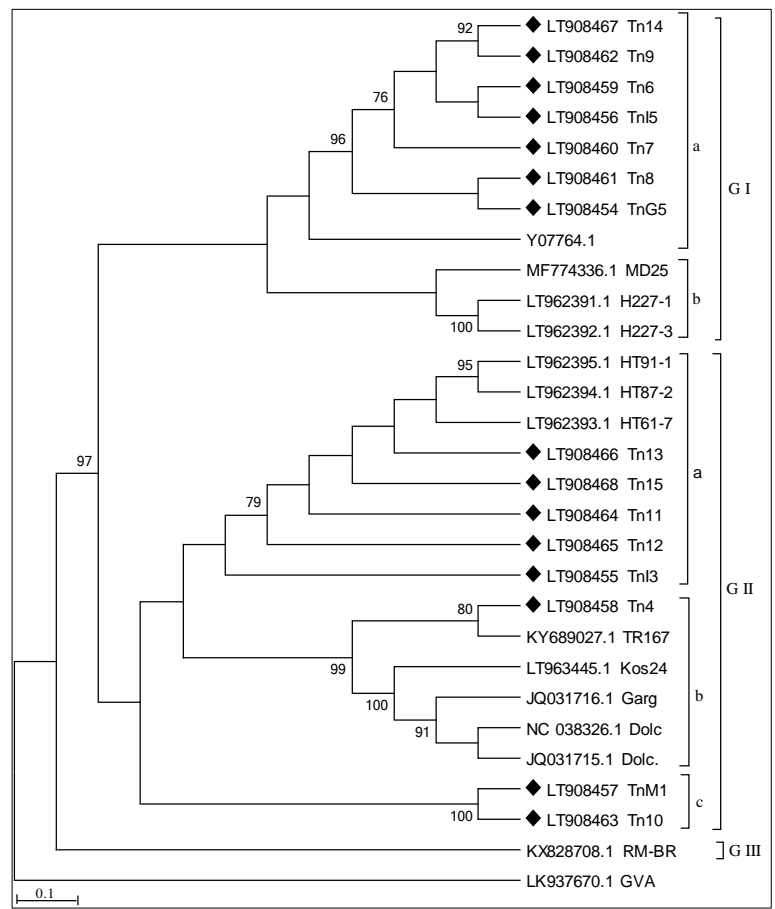

Fig. 1. Phylogenetic tree constructed based on nucleotide sequences of partial CP genes of GVD isolates obtained in this study (indicated with a diamond) and those available in GenBank.The percentage support of bootstrap (>75\%) from 1000 replicates. Accessions numbers are followed by isolates names. G: Group. 


\section{DISCUSSION}

The present study has shown a high prevalence $(31.5 \%)$ of GVD infections in the Tunisian vineyards, a value relatively similar to that of $41.4 \%$ reported in a previous survey (Mahfoudhi et al. 2014).

The high infection rate of GVD, especially in table grapes, together with the high incidence of other viruses in the Tunisian vineyards (Mahfoudhi et al. 1998) reveal an alarming situation for viticulture in the country. GVD is the least studied among all the rugose woodassociated viruses, and its prevalence has only been assessed in a few countries. A similar GVD-infection rate $(31 \%)$ was reported in grapevines from Italy (Boscia et al. 2001), whereas it was significantly lower (9\%) in Turkey (Buzkan et al. 2017).

Despite the natural vector of GVD is still unknown, the high rate of infection by this virus could be due to the presence of a still unidentified vector, especially since the mealybugs, i.e. Planococcus ficus and Planococcus citri known to be involved in the dissemination of other vitiviruses associated with rugose wood disease are very widespread in Tunisia (Mahfoudhi and Dhouibi 2009).

This work provides information on the genetic diversity of GVD in the Tunisian grapevines based on the sequence comparison of a fragment of the $\mathrm{CP}$ gene. In the phylogenetic analysis, the Tunisian isolates clustered into two groups, and in particular in Group II (8 isolates) and
Group I (7 isolates). It is worth noting that most of these isolates were grouped into two subgroups (I-a and II-a), thus suggesting the existence of a large variability among Tunisian GVD-isolates.

The high divergence found between GVD-isolates, based on the sequence analysis of $\mathrm{CP}$ gene, with the presence of six GVD-clusters (considering groups and subgroups), confirms the high genetic diversity of this virus as that reported for other vitiviruses (Elbeaino et al. 2019).

Furthermore, the segregation of Tunisian GVD isolates into different phylogenetic groups regardless of the grapevine plant material type, cultivars, but not the geographical origin as is the case of Tunisian and Italian isolates found close to each other in the phylogenetic tree, suggests that GVD isolates from Tunisia and Italy had a common origin (Elbeaino et al. 2019).

This study extends the knowledge on the incidence of GVD in the Tunisian vineyards and provides the first molecular information on the high sequence variability that could be exploited to develop broad-spectrum molecular diagnostics (RT-PCR) for the detection of different GVD isolates infecting grapevine in nature.

\section{ACKNOWLEDGEMENTS}

This work was financed in part by the Tunisian-Algerian Cooperation, as part of the INNOVITIS project "Valorisation et innovations dans l'utilisation des vignes autochtones nordafricaines".

\section{RESUME}

Selmi I., Elbeaino T., Arezki L., El Air M., Digiaro M. et Mahfoudhi N. 2021. Prévalence et diversité génétique du virus $D$ de la vigne en Tunisie. Tunisian Journal of Plant Protection 16 (2): 19-27.

La prévalence et la diversité génétique des isolats du virus D de la vigne (GVD) provenant de porte-greffes, de cépages de cuve et de variétés de table (introduites et autochtones) cultivés en Tunisie ont été étudiées. Les tests RT-PCR effectués sur le gène de la protéine de la capside 
(CP) ont montré la présence de GVD dans 31,5\% des 403 échantillons testés. Le taux d'infection le plus élevé a été trouvé dans les variétés de table introduites $(56,5 \%)$, suivis par les variétés de table autochtones $(24,1 \%)$, les cépages de cuve $(20,8 \%)$ et les porte-greffes $(12,5 \%)$. Les séquences et les analyses phylogénétiques des gènes partiels du CP de 14 isolats de GVD ont montré des identités nucléotidiques allant de $84 \%$ à $99 \%$. Les isolats tunisiens du GVD ont été groupés en 3 groupes phylogénétiques avec les isolats internationaux inscrits dans le GenBank. La présente étude élargie nos connaissances sur la présence de GVD dans les vignes tunisiennes et sur sa diversité génétique, ce qui est utile pour développer le diagnostic moléculaire à large spectre capables de détecter les différents isolats infectant la vigne.

Mots clés: Vigne, analyses phylogénétiques, RT-PCR, séquences, vitivirus

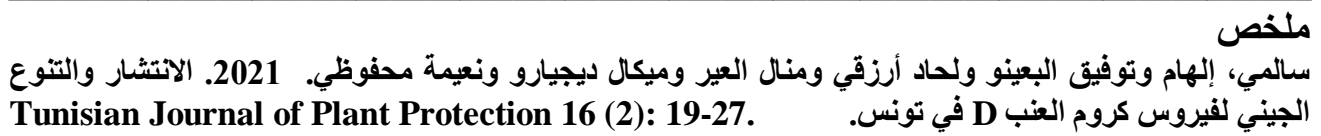

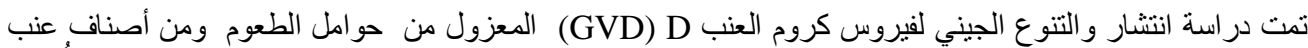

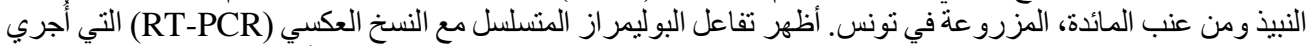

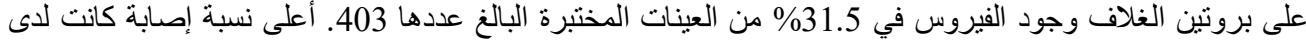

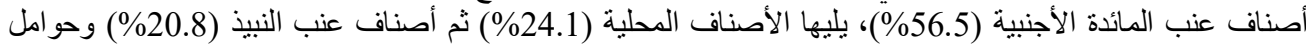

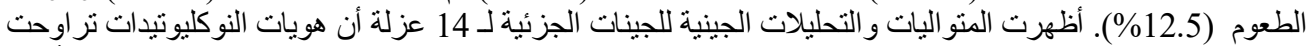

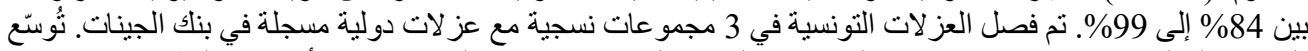

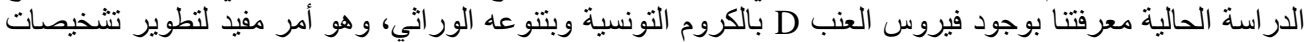

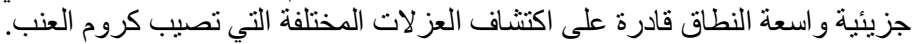

كلمات مفتاحية: تحاليل جينية، تسلسل، كروم العنب، vitivirus ،RT-PCR

\section{LITERATURE CITED}

Abou-Ghanem, N., Saldarelli, P., Minafra, A., Buzkan, N., Castellano, M.A., and Martelli, G.P. 1997. Properties of grapevine virus D, a novel putative Trichovirus. Journal of Plant Pathology 78: 15-25.

Al Rwahnih, M., Sudarshana, M.R., Uyemoto, J.K., and Rowhani, A. 2012. Complete genome sequence of a novel vitivirus isolate from grapevine. Journal of Virology 86 (17): 9545. https://doi.org/ 10.1128/JVI.01444-12

Alabi, O.J., McBride, S., Appel, D.N., Al Rwahnih, M., and Pontasch, F.M. 2019. Grapevine virus $\mathrm{M}$, a novel vitivirus discovered in the American hybrid bunch grape cultivar Blanc du Bois in Texas. Archives of Virology 164: 1739-174. https://doi.org/10.1007/s00705-019-04252-7

Blouin, A.G., Chooi, K.M., Warren, B., Napier, K.R., Barrero, R.A., and MacDiarmid, R.M. 2018 b. Grapevine virus I, a putative new vitivirus detected in coinfection with grapevine virus $\mathrm{G}$ in New Zealand. Archives of Virology 163:
1371-1374. https://doi.org/10.1007/s00705018-3738-5

Blouin, A.G., Keenan, S., Napier, K.R., Barrero, R.A., and MacDiarmid, R.M. 2018a. Identification of a novel vitivirus from grapevines in New Zealand. Archives of Virology 163: 281-284. https://doi.org/10.1007/s00705-017-3581-0.

Bonavia, M., Digiaro, M., Boscia, D., Boari, A., Bottalico, G., and Savino, V. 1996. Studies on "corky rugose wood" of grapevine and on the diagnosis of grapevine virus B. Vitis 35: 53-58.

Boscia, D., Digiaro, M., Safi, M., Garau, R., Zhou, Z., Minafra, A., Abou-Ghanem, N., Sabanadzovic, S., Bottalico, G., and Potere, O. 2001. Production of monoclonal antibodies to Grapevine virus D and contribution to the study of its aetiological role in grapevine disease. Vitis 40: 64-74.

Buzkan, N., Öztırak, M.K., and Balsak, S.C. 2017. First report of Grapevine virus D (GVD) in 
autochthonous grapevine varieties in Turkey. Journal of Plant Pathology99: 803.

Candresse, T., Theil, S., Faure, C., and Marais, A. 2018. Determination of the complete genomic sequence of grapevine virus $\mathrm{H}$, a novel vitivirus infecting grapevine. Archives of Virology 163: 277-280. https://doi.org/10.1007/s00705-017$\underline{3587-7}$

Chevalier, S., Greif, C., Clauzel, J-M., Walter, B., and Fritsch, C. 1995. Use of an immunocapture polymerase chain reaction procedure for the detection of Grapevine virus A in Kober stem grooving infected grapevines. Journal of Phytopathology 143: 369-373

Choueiri, E., Abou-Ghanem, N., and Boscia, D. 1997. Grapevine virus A and Grapevine virus D are serologically distantly related. Vitis 36 : 39 41

Debat, H., Zavallo, D., Brisbane, R.S., Vončina, D., Almeida, R.P.P., Blouin, A.G., Al Rwahnih, M., Gomez-Talquenca, S., and Asurmendi, S. 2019. Grapevine virus L: a novel vitivirus in grapevine. European Journal of Plant Pathology 155: 319-328. https://doi.org/10.1101/314674

Diaz-Lara, A., Golino, D., and Al Rwahnih, M. 2018.Genomic characterization of grapevine virus $\mathrm{J}$, a novel virus identified in grapevine. Archives of Virology 163: 19651967. https://doi.org/10.1007/s00705-0183793-y

Digiaro, M., PopovicBedzrob, M., D’Onghia, A.M., Boscia, D., and Savino, V. 1994. On the correlation between grapevine virus $\mathrm{A}$ and rugose wood. Phytopathologia Mediterranea 33: 187-193.

Elbeaino, T., Chammem, H., Alsaheli, Z., Ben Slimen, A., and Digiaro, M. 2019. Development of RT-PCR assays for the detection and the resultant phylogenetic analysis of four grapevine vitiviruses based on the coat protein sequences. Journal of Virological Methods 113712. https://doi.org/10.1016/j.jviromet.2019.113712

Foissac, X., Svanella-Dumas, L., Gentit, P., Dulucq, M.J., and Candresse, T. 2001. Polyvalent detection of fruit tree Tricho, Capillo and Foveavirus by nested RT-PCR using degenerated and inosine containing primers (DOP RT-PCR). Acta Horticulturae 550: 37 43

Garau, R., Prota, V.A., Piredda, R., Boscia, D., and Prota, U. 1994. On the presence of possible relationship between Kober stem grooving and Grapevine virus A. Vitis 33: 161-163.

Kumar, S., Stecher, G., and Tamura, K. 2016. MEGA7: Molecular evolutionary genetics analysis version 7.0 for bigger datasets. Molecular Biological Evolutionary 33: 18701874. https://doi.org/10.1093/molbev/msw054

Mahfoudhi, N., and Dhouibi, M.H. 2009. Survey of mealybugs (Hemiptera: Pseudococcidae) and their natural enemies in Tunisian vineyards. African Entomology17: 154-160. https://doi.org/10.4001/003.017.0205

Mahfoudhi, N., Digiaro, M., Savino, V., and Di Terlizzi, B. 1998. Viruses and virus diseases of grapevine in Tunisia. EPPO Bulletin 28: $197-$ 204.

Mahfoudhi, N., Soltani, I., El Air, M., Digiaro, M., and Elbeaino, T. 2014. Occurrence and widespread distribution of Grapevine virus D in Tunisian grapevines. Journal of Plant Pathology 96 (2): 431. http://dx.doi.org/10.4454/JPP.V96I2.001

Martelli, G.P. 2014. Directory of virus and virus-like diseases of the grapevine and their agents. Journal of Plant Pathology 96: 1-136

Martelli, G.P., and Boudon-Padieu, E. 2006 Directory of infectious diseases of grapevine and viroses and virus-like diseases of the grapevine: Bibliographic report 1998-2004. Options Méditerranéennes Serie B, N55, 279.

Nakaune, R., Toda, S., Mochizukki, M., Nakano, M. 2008. Identification and characterization of a new vitivirus from grapevine. Archives of Virology 153: 1827-1832. https://doi.org/10.1007/s00705-008-0188-5

Rowhani, A., Daubert, S., Arnold, K., Al Rwahnih, M., Klaassen, V., Golino, D., and Uyemoto, J.K. 2018. Synergy between grapevine vitiviruses and grapevine leafroll viruses. European Journal of Plant Pathology 4: 919 925. https://doi.org/10.1007/s10658-018-1426$\underline{7}$ 


\title{
Evaluation under Laboratory Conditions of the Efficacy of Four Extracts of Spontaneous Plants from the Mzab Valley (Algeria) against the Date Palm Mite (Oligonychus afrasiaticus)
}

Younes Babaz, Omar Guezoul, Laboratoire des Bio-ressources Sahariennes: Préservation et Valorisation, Département des Sciences Agronomiques, Faculté des Sciences de la Nature et la Vie et Sciences de la Terre. Université Kasdi Merbah, BP 511, Ouargla 30000, Algeria, and Noureddine Bouras, Département de Biologie, Faculté des Sciences de la Nature et de la Vie et Sciences de la Terre, Université de Ghardaïa, 47000 Ghardaïa, Algeria https://doi.org/10.52543/tjpp.16.2.2

(Algeria)

\begin{abstract}
Babaz, Y., Guezoul, O., and Bouras, N. 2021. Evaluation under laboratory conditions of the efficacy of four extracts of spontaneous plants from the Mzab Valley (Algeria) against the date palm mite (Oligonychus afrasiaticus). Tunisian Journal of Plant Protection 16 (2): 29-41.

Trials were conducted to test the hydrosols of 4 spontaneous plants on the date palm mite, Oligonychus afrasiaticus, a key pest of date palm in Algeria. Extracts from those plants (basil, harmel, colocynth and hyssop) tested against date palm mite showed promising results. The quantities of essential oils extracted from the 4 plants were extremely low, that is why only hydrosols were used. The results obtained change depending on the number of sprays and the reading time after treatment. The hyssop extract caused a high mortality rate of $91 \%$, followed by colocynth and basil extracts with average mortality rates of $64 \%$ and $62 \%$, respectively. The lowest mortality rate, $6 \%$, occurred when applying harmel extract.
\end{abstract}

Keywords: Date palm, mite, Oligonychus afrasiaticus, plant extracts, septentrional Sahara, spontaneous plant

Among the pests of date palm (Phoenix dactylifera), the scale insect Parlatoria blanchardi, the moth Apomyelois (syn Ectomyelois) ceratoniae, the black borer Apate monachus, and the mites Oligonychus pratensis (syn Paratetranychus simplex) and Oligonychus afrasiaticus are the most

Corresponding author: Younes Babaz

Email: babazyounes@gmail.com

Accepted for publication 11 September 2021 important. The latter species causes serious scars on the fruits, sometimes so severe that the dates become brown with a crusty appearance. The skin of infested fruits becomes hard, then cracks and wrinkles, reducing the quality and making such fruit unmarketable (Hussain 1974; De Montaigne and Fall 1986; Guessoum 1986). The various control methods available have not provided the desired level control of mites in palm groves, particularly chemical pesticides. Hence, the overuse of pesticides (acaricide) has shown multiple negative side effects, and 
several disadvantages have been noted after the use of these synthetic products (Doumandji-Mitiche and Doumandji 1993). The intensive use, and sometimes overuse of chemicals to control Oligonychus afrasiaticus, resulted in multiple resistance cases (Hay and Waterman 1993; Singh and Upadhyyay 1993; Isman 2000, 2001; Chiasson et al. 2001; Basta and Spooner-Hart 2002). However, natural plant extracts can be the source of a large number of acaricide and insecticide products (Isman 2001).

There is growing interest from farmers in biopesticides, including their use in integrated pest management strategies (Jovana et al. 2014). Biopesticides could be defined as "living organisms or products of these organisms with the ability to limit or suppress crop pests" (Thakore 2006). It is in biopesticides that we search for alternatives to control Oligonychus afrasiaticus through appropriate integrated control trials in palm groves, in the Mzab region, Algeria (Fig. 1). Biological control through the use of plant extracts could provide alternatives to chemical control and may be combined with other control methods that are not harmful to the environment.

Extracts of some plant species have been shown to act as biopesticides against other pest species. This includes Peganum harmala (Zygophyllaceae), which is toxic to the desert locust Schistocerca gregaria when digested (Idrissi Hassani et al. 2008). Abbassi et al. (2003) reported that the use of $P$. harmala leaf extracts on female desert locusts leads to reduce food intake, motor skills, and disturbances of the reproductive function. Moreover, Bruneton (2016) reported that the hyssop contains pinocamphone and isopinocamphone, which are neurotoxic ketones (causing convulsions and tetany).
Neurotoxicity may be related to the inhibitory action of these ketones on cellular respiration. Akono et al. (2012) reported that Ocimum basilicum oil contains a majority of monoterpene hydrocarbons $\quad(56.2 \%)$. Bioassays undertaken according to the World Health Organization (WHO) standard protocol showed that these volatile essences have remarkable insecticidal properties.

The purpose of this work is to evaluate the acaricidal effect of plant extracts (hydrosol) against the date palm mite, Oligonychus afrasiaticus, which causes enormous damages to date production in the region. Four plant species were collected in the area of Touzouz (Municipality of Ghardaïa), and N'tissa (Municipality of Bounoura), during the month of July 2018. From these plants, the active ingredients were extracted, in order to test their efficacy, under laboratory conditions, as bioacaricid to control this mite of date palm.

\section{MATERIALS AND METHODS Plant materials.}

Four plant species were used for the extraction of essential oils (EO) and the recovery of their hydrosols: Ocimum basilicum (basil), Hyssopus officinalis (hyssop), Peganum harmala (harmel) and Citrullus colocynthis (colocynth) (Fig. 2).

The plants were collected at dawn, then left out to dry in the shade for few days. The entire aerial part was used in the extraction procedure. Two plants (basil and hyssop) were collected from Touzouz area (Ghardaïa municipality, Ghardaiia governorate) in a palm grove operating in an oasis production system (date palms, arboriculture and vegetables). However, harmel and colocynth were collected from a natural non-cultivated environment from N'tissa area (Bounoura municipality, Ghardaïa governorate). 


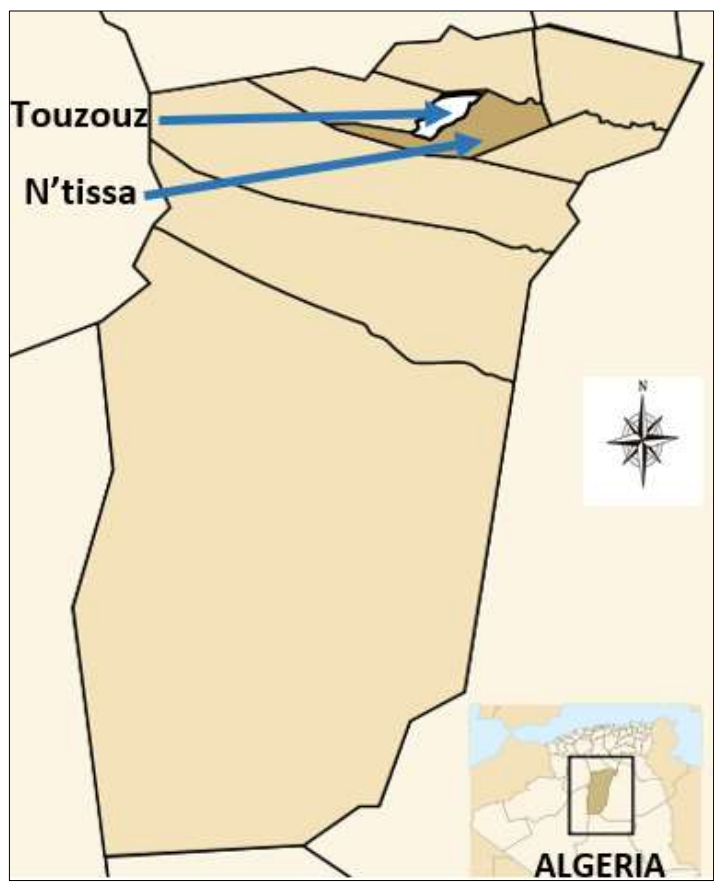

Fig. 1. Geographical location of Tzouzou and N'tissa areas in Ghardaïa governorate.


Fig. 2. Basil (1), Hyssop (2), Harmel (3) and Colocynth (4). 


\section{Extraction process and determination of extraction yield.}

The selection of an extraction method depends on the quality sought and on the nature of the plant material to be extracted. Extraction of the essential oil and hydrosol were carried out under laboratory conditions by using an hydrodistillation procedure (both essential oil and hydrosol were collected by the same technique). The operation consists in immersing the aerial parts of the dried plant into a round bottom flask of 2 liters volume, filled with distilled water up to $2 / 3$, then boiled for $4 \mathrm{~h}$. The essential oil is then driven by water vapor and condensed through the capacitor. The collected liquid results in a distillate with a thin layer of oil on the surface, which will be separated with a settling bulb, after resting the liquid. The collected hydrosol is stored hermetically in sealed glass bottles and kept under cool conditions.

According to AFNOR (1986), the yield of essential oil (EO) is defined as the ratio between the mass of the essential oil obtained after extraction ( $\left.\mathrm{M}^{\prime}\right)$ and the mass of the plant material used (M). It is given by the following formula:

$$
\mathrm{EO}=\left(\mathrm{M}^{\prime} / \mathrm{M}\right) \cdot 100
$$

where EO: Essential oil yield of each plant, M': Mass of the obtained essential oil (g), M: Mass of the used plants (g).

\section{Mite collection.}

Infested date fruits of cultivar Deglet-Nour were used as the source of mites (Fig. 3). Mites move quickly from infested to healthy fruits. The initial number of mobile mites (larvae, protonymphs, deutonymphs and adults) was counted prior to each treatment (after placing the mite boxes in the refrigerator at $4^{\circ} \mathrm{C}$ for $30 \mathrm{~min}$, to slow down the activity of mites). The starting number of mite individuals was adjusted to 100 , no matter the stage, by gently removing additional mites with a very fine brush.

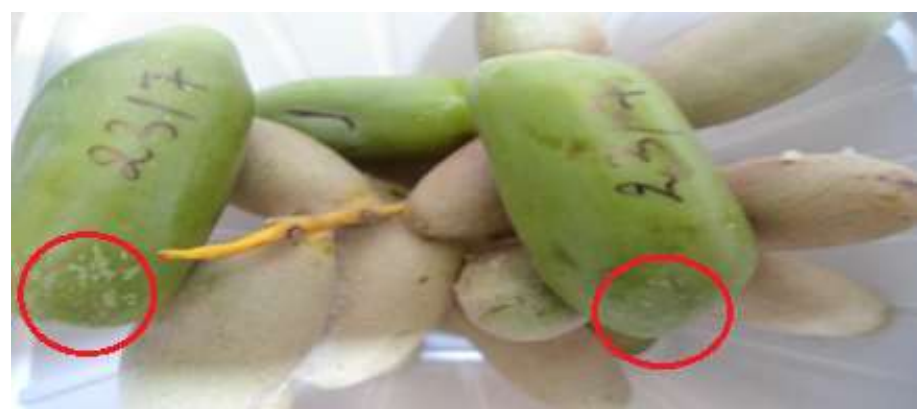

Fig. 3. Migration of mites from infested to healthy date fruits (inside the circles).

\section{Treatments.}

Manual sprayer $(500 \mathrm{ml})$ was used for all treatments of the mite individuals on fruits under constant temperature and humidity of $32^{\circ} \mathrm{C}$ and $20 \%$, respectively, in the laboratory. The treated fruits were placed in four plastic boxes $(30 \times 20 \times 15 \mathrm{~cm})$, lined with blotting dry paper and covered by Muslin fabric. The hydrosol of each plant was applied to three fruits. One spray of the sprayer delivers a $0.80 \mathrm{ml}$ volume. The 
number of sprays ranged from one to four, resulting in a total treatment volume from 0.8 to $3.2 \mathrm{ml}$ (Fig. 4). There were three replicates for each treatment plus one negative control (with only water) common to all plants. Over time, four measurements spaced of two hours (after
2, 4, 6 and 8 hours) were performed to determine the mite mortality rates which were evaluated by counting the living and dead mites before and after treatment, using a binocular magnifier and an electronic hand meter.

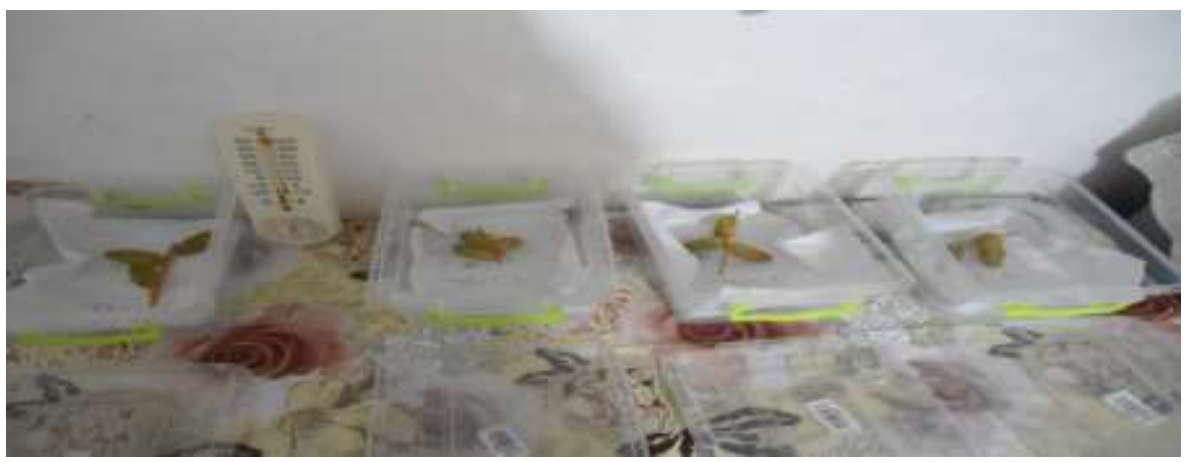

Fig. 4. Treatments of three dates in each plastic box and each treatment was replicated three times.

\section{Statistical analysis.}

We compared the mite mortality rates associated with the different plant hydrosol treatments, using statistical analysis performed in R software (1953). We therefore verified the Shapiro-Wilk normality test, then adopted the KrukalWallis test to compare mortality rates under the influence of various factors, namely, plant species, number of sprays and timing of the observations.

The calculation of the ShapiroWilk test of normality gave a $P<5 \%$, indicating that the data did not have a normal distribution. The Krukal-Wallis test was then used for the observation times after treatment and on the number of sprays per treatment.

\section{RESULTS}

\section{Essential oils and hydrosol yield.}

The first observation in Table 1 shows extremely low yields of essential oils obtained from the four plants. The lowest was from colocynth at $0.2 \%$. The highest is that of hyssop which is around $0.5 \%$. On the other hand, the quantities of hydrosols obtained were relatively large, ranging from 600 to $720 \mathrm{ml}$.

Table 1. Plants evaluated for their acaricidal activity against Oligonychus afrasiaticus, their essential oil yield and their hydrosol amount

\begin{tabular}{l|lccc}
\hline \multicolumn{1}{c|}{ Scientific name } & \multicolumn{1}{c}{ Family } & $\begin{array}{c}\text { Used plant } \\
\text { parts }\end{array}$ & $\begin{array}{c}\text { Oil yield } \\
(\%)\end{array}$ & $\begin{array}{c}\text { Collected } \\
\text { hydrosol (ml) }\end{array}$ \\
\hline Ocimum basilicum & Lamiaceae & & 0.40 & 650 \\
Hyssopus officinalis & Lamiaceae & All & 0.50 & 720 \\
Peganum harmala & Zygophyllaceae & & 0.46 & 600 \\
Citrullus colocynthis & Cucurbitaceae & & 0.20 & 640 \\
\hline
\end{tabular}


Extract toxicity (hydrosol) effect.

Figs. 5, 6 and 7, show that the highest mite mortality rate is recorded for hyssop hydrosol, which varies between $17 \%$ for $2 \mathrm{~h}$ after 2 sprays and up to $91 \%$ for $8 \mathrm{~h}$ after 4 sprays. The next most efficacious hydrosol was from colocynth, characterized by a relatively strong acaricidal effect, with a mortality rate varying between $12 \%$ and $64 \%$, whereas the lowest rate is observed with harmel hydrosol, which ranges from $0 \%$ for $2 \mathrm{~h}$ after 2 sprays to $2 \%$ for $8 \mathrm{~h}$ after application of 4 sprays. Basil hydrosol generally had a delayed acaricidal effect, initially displaying a weak effect and then producing variable mortality, ranging between $0 \%$ and $62 \%$.

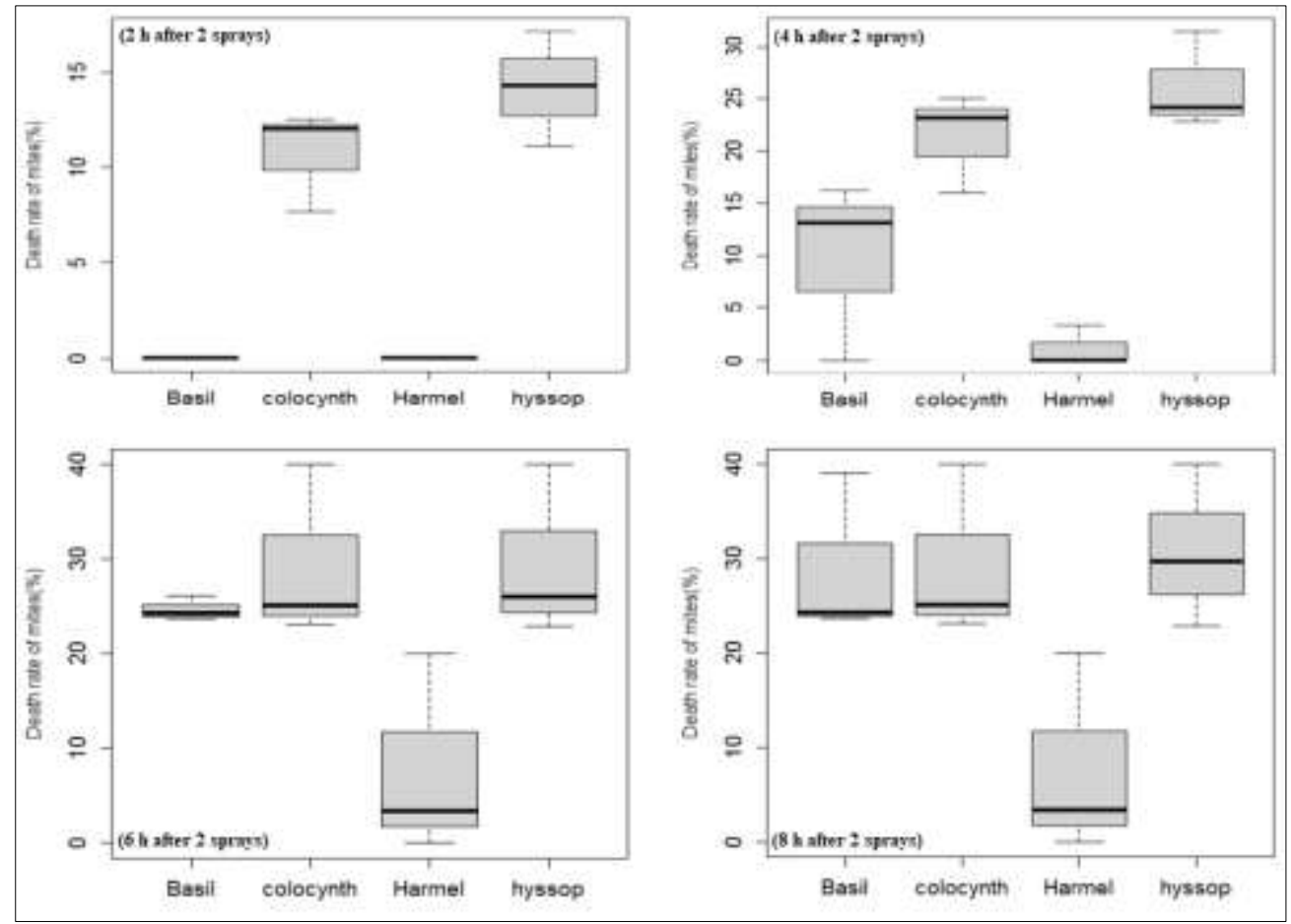

Fig. 5. Mite mortality rate according to the hydrosols of the 4 plants over 4 observation times, after 2 sprays. The bold horizontal segments are the medians. The dotted vertical segments are the standard deviations.

After 2 sprays, Fig. 5 illustrates the late acaricidal effect of the hydrosols of the two plants, basil and harmel. These extracts increase slowly the mortality rates of the mites over time, while extracts of colocynth and hyssop produce higher mortality relatively early, already 2 hours after treatment. 


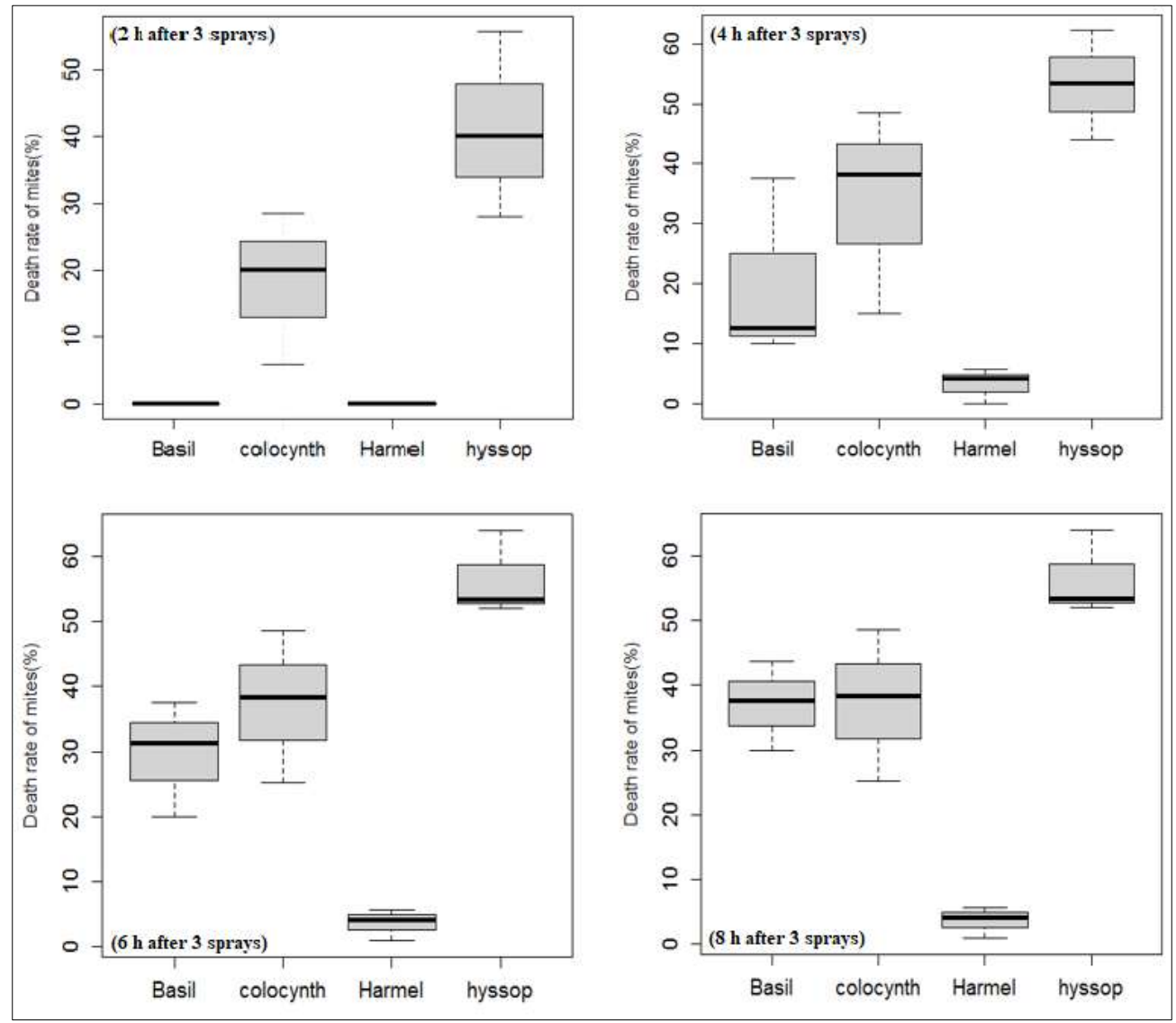

Fig. 6. Mite mortality rate according to the hydrosols of the 4 plants over 4 observation times, after 3 sprays. The bold horizontal segments are the medians. The dotted vertical segments are the standard deviations.

After 3 sprays, the result shown in Fig. 6 is a low or even neutral acaricidal effect of harmel hydrosol in comparison with that of hyssop, during all 4 phases of observation. On the other hand, the mite mortality rates for hydrosols of the other two plants basil and colocynth remain relatively stable, particularly for the last 2 observations. 


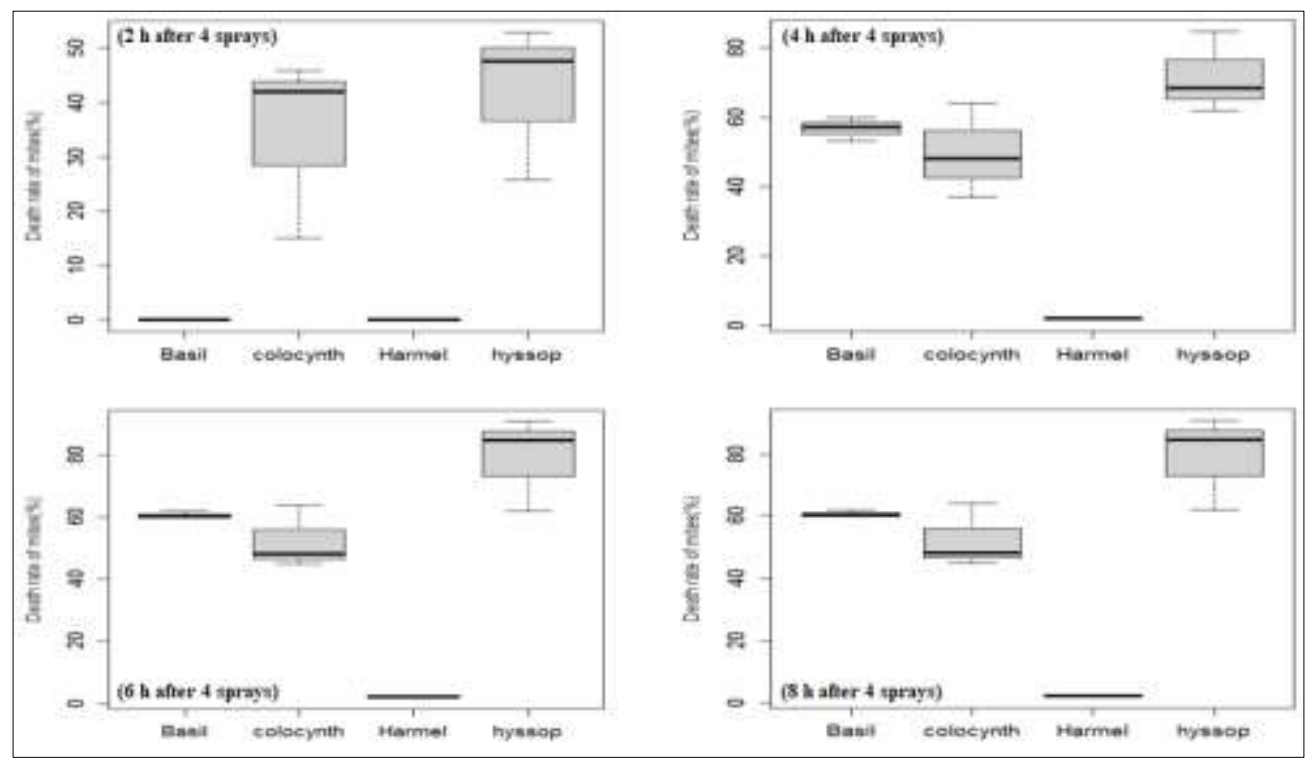

Fig. 7. Mite mortality rate according to the hydrosols of the 4 plants over 4 observation times, after 4 sprays. The bold horizontal segments are the medians. The dotted vertical segments are the standard deviations.

After 4 sprays, indication of Fig. 7 is the lack of acaricidal effect from harmel at all 4 observation phases. The hydrosol of hyssop has a strong acaricidal effect and exhibits the highest mortality rate after 4 sprays and at all 4 observation phases. The hydrosol of basil and colocynth expresses a relatively important acaricidal effect for 4 sprays and during the 4 observation phases, except for basil at the first time $(2 \mathrm{~h})$ of treatment, where the effect is poor.

\section{Mite mortality rates based on the plant hydrosols.}

Kruskal-Wallis test calculations gave the following results: $\chi^{2}=69.567$, df $=3, P$-value $=5.285 \mathrm{e}^{-15}$.

The $P$-value reflects the existence of a highly significant difference between the medians of the 4 groups (Fig. 8).

In order to determine the difference between the 4 groups, multiple comparison tests were performed using the Bonferroni adjustment method (Table 3).

Table 3. Level of difference in mite mortality rates due to the hydrosols of 4 plants

\begin{tabular}{c|ccc}
\hline & Basil & Colocynth & Hyssop \\
\hline Colocynth & 0.79210 & - & - \\
Hyssop & 0.00362 & 0.03644 & - \\
Harmel & 0.00038 & $5.1 \mathrm{e}-12$ & $2.4 \mathrm{e}-12$ \\
\hline
\end{tabular}


The lowest acaricidal effect reported is that of harmel hydrosol with a maximum mortality rate of $6 \%$. The highest is that of hyssop with the maximum mortality rate reaching $91 \%$.
The intermediate acaricidal effect is obtained by the hydrosols of the two plants, basil and colocynth, with corresponding consecutive maximum mortality rates of $62 \%$ and $64 \%$ (Fig. 8).

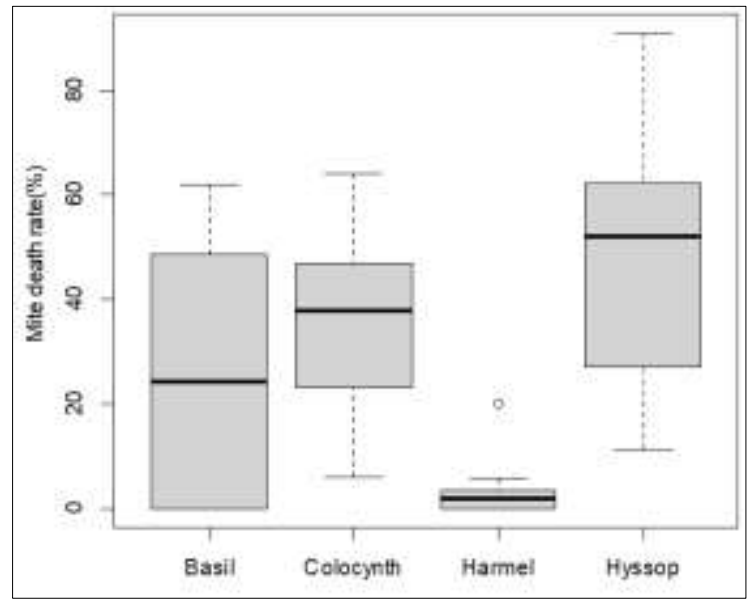

Fig. 8. Effect of hydrosols from 4 plants on the mite mortality rate. The bold horizontal segments are the medians. The dotted vertical segments are the standard deviations.

\section{Mite mortality rates based on the observation times.}

The calculation of the KruskalWallis test gave the following results: $\chi^{2}=$ $24.091, \mathrm{df}=3, P$-value $=2.391 \mathrm{e}^{-05}$.
The $P$-value reflects the existence of a highly significant difference between the medians of the 4 groups studied (Table 4).

Table 4. Level of difference in mite mortality rates between 4 observation times after treatment

\begin{tabular}{l|ccc}
\hline & 2 hours & 4 hours & 6 hours \\
\hline 4 hours & 0.00677 & - & - \\
6 hours & 0.00020 & 1.00000 & - \\
8 hours & 0.00012 & 1.00000 & 1.00000 \\
\hline
\end{tabular}


Mite mortality rates of mites based on the number of sprays

The calculation of the KruskalWallis test gave the following results: $\chi^{2}=$ $17.114, \mathrm{df}=2, P$-value $=0.0001922$.
The $P$-value reflects the existence of a highly significant difference between the 4 groups studied (Table 5).

Table 5. Level of difference in mite mortality rates between the numbers of applied sprays

\begin{tabular}{l|cc}
\hline & 2 sprays & 3 sprays \\
\hline 3 sprays & 0.04905 & - \\
4 sprays & 0.00038 & 0.06236 \\
\hline
\end{tabular}

\section{DISCUSSION}

There are different methods for extracting bioactive compounds from aromatic, tinctorial and lignocellulosic rich plants such as cold expression, volatile organic solvent, liquefied gas, fluid in the supercritical state, microwave, ultrasonic, water vapor, and hydrodistillation (Peyron and Richard 1992; Qin 1993; Sankarikutty and Narayanan 1993; Starmans and Nijhuis 1996; Martini and Seiller 1999; Wang and Weller 2006). Among all these processes, hydrodistillation is the most widely used in industrial production of essential oils (Mastelic 2001). The main reasons for this preference are related to the ease of implementation of the process, its selectivity and therefore the quality of the products obtained. Furthermore, hydrodistillation facilities are relatively simple to design and construct (Ganou 1993).

In our work, the resulting essential oil (EO) yields were extremely low (not exceeding $0.4 \%$ for basil). Akono et al. (2012) reported a yield of $0.11 \%$ EO for $O$. basilicum using the hydrodistillation technique. Additionally, Rey et al. (2004) reported a yield of $0.57 \%$ EO for H. officinalis in the fruiting phase, which is not far from the result of the Tunisian Journal of Plant Protection present study (for the same phenological stage of the plant). According to Idrissi Hassani (1999), the EO yield of Peganum harmala seeds reached $10 \%$.

The first observation is the fairly significant bioacaricidal effect of hyssop, compared to the other 3 plants studied. It should also be noted that the greater the quantity of hydrosol applied to the pest and the longer the product is left to act, the higher is the mortality rate, with the exception of harmel hydrosol.

The $P$-values resulting from the Kruscal-Wallis test revealed the existence of differences in the acaricidal effect between the plants studied, particularly between hyssop and harmel. Indeed, hyssop differs from other plants by the release of strong odors which, according to Attou (2017) originate from a set of products such as ketones and diketones (diones) and the neurotoxicity is explained by the strong affinity of ketones to lipids; this results in passage through the bloodbrain barrier, destruction of the myelin sheaths and electrical disturbances of neurons with excitation then depression, which are probably the cause of the death of mites. The difference is clearly apparent in the death rates between the 4 observation times. This can explain how the product acts on the pest, which is 
probably by contact acting on the mite's synapses and neurotransmitters. Piochon (2008) stated that several hydrosols exerted interesting biological activities and sometimes stronger than that of the corresponding essential oil. The use of biopesticides against this pest mite, in view of their importance, has been the subject of several recent studies, such as that of Archita et al. (2015) and Júnior de Andrade et al. (2020). This study supports the suggestion that plant extracts are potentially useful biopesticides for combating agricultural pests while preserving the environment. It would therefore be interesting to study and explore the biopesticide effects of other spontaneous or cultivated plants and to extend their use in order to minimize the use of chemical pesticides harmful to man and his environment.

\section{RESUME}

Babaz Y., Guezoul O. et Bouras N. 2021. Evaluation en conditions de laboratoire de l'efficacité de quatre extraits de plantes spontanées de la Vallée du Mzab (Algérie) contre l'acarien du palmier dattier (Oligonychus afrasiaticus). Tunisian Journal of Plant Protection 16 (2): 29-41.

Des essais ont été menés, pour tester les hydrolats de 4 plantes spontanées, sur l'acarien du palmier dattier, Oligonychus afrasiaticus, un ravageur du palmier dattier important en Algérie. Les extraits de ces plantes (basilic, Harmel, coloquinte et hysope) testés contre l'acarien du palmier dattier ont donné des résultats prometteurs. Les quantités d'huiles essentielles extraites des 4 plantes étaient extrêmement faibles, c'est pourquoi seuls des hydrolats ont été utilisés. Les résultats obtenus varient en fonction du nombre de pulvérisations et du temps de lecture après le traitement. L'extrait d'hysope a provoqué un taux de mortalité élevé de $91 \%$, suivi des extraits de coloquinte et de basilic avec des taux de mortalité moyens de $64 \%$ et $62 \%$, respectivement. Le taux de mortalité le plus faible, soit $6 \%$, s'est exprimé lors de l'application de l'extrait de harmel.

Mots clés : Acarien, extraits de plantes, Oligonychus afrasiaticus, palmier dattier, plantes spontanées, Sahara septentrional

ملقيم كفاعة أربعة مستخلصات نباتات برية في ظروف المخبر ضد حلم نخيل التمر (بوفروه/الغبيره/حلم الغبار، (Oligonychus afrasiaticus Tunisian Journal of Plant Protection 16 (2): 29-41.

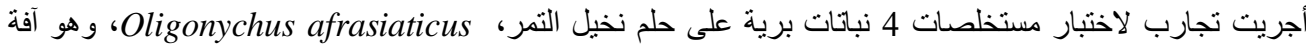

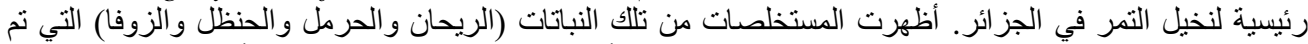

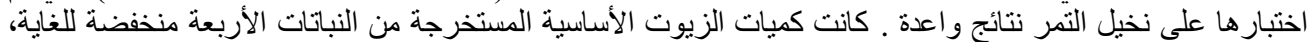

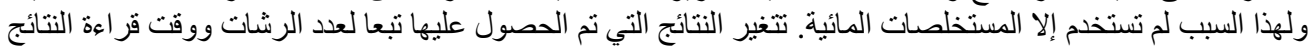

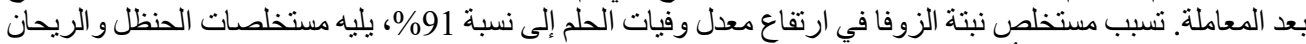

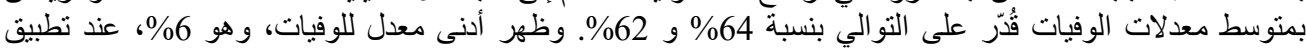

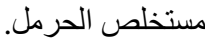

كلمات مفتاحية: حلم، الصحر اء الثمالية، مستخلصات نباتية، نخيل التمر، نباتات برية، Oligonychus afrasiaticus 


\section{LITERATURE CITED}

Abbassi, K., Mergaoui, L., Atay-Kadiri, Z., Stambouli, A., and Ghaout, S. 2003. Effets des extraits de Peganum harmala (Zygophyllacae) sur le criquet pèlerin (Schistocerca gregaria Forskål, 1775). Zoologica baetica, 13/14: 203-217.

Afnor, 1986. Recueil des Normes Française, huiles essentielles, AFNOR. Paris, France, 57 pp.

Akono, N.P., Belong, P., Tchoumbougnang, F., Bakwo Fils, E.M., and Fankem, H. 2012. Effets insecticides des huiles essentielles des feuilles Ocimum spp. sur les adultes d'Anopheles funestus. Journal of Applied Biosciences 59: 4340-4348.

Archita, B. Somnath, R., Gautam, H., Foridur Rahman, B., Azizur, R., Dwiban, P., and Narayanannair M. 2015. Clove Oil Efficacy on the Red Spider Mite, Oligonychus coffeae Nietner (Acari: Tetranychidae) Infesting Tea Plants. Zoological Society, Kolkata, India 1: 92-96.

Attou, A. 2017. Détermination de la composition chimique des huiles essentielles de quatre plantes aromatiques de l'ouest algérien (Région d'Ain Témouchent) étude de leurs activités antioxydante et antimicrobienne. Thèse de Doctorat, Université de Tlemcene, Algérie, 82 pp.

Basta, A., and Spooner-Hart, R.N. 2002. Efficacy of an extract of dorrigo pepper against twospotted mite and greenhouse thrips. Pages 471-476. In: Spray oils beyond 2000. Beattie, G.A.C., Waston, D.M., Stevens, M.L., Rae, D.J., and Spooner-Hart, R.N, Eds. University of Western Sydney, Sydney, Australia.

Bruneton, J. 2016. Pharmacognosie - Phytochimie, plantes médicinales - ( $5^{\circ}$ Edition). Lavoisier. France, $1488 \mathrm{p}$

Chiasson, H., Belanger, A., Bostanian, N., Vincent, C., and Poliquin, A. 2001. Acaricidal properties of Artemisia absinthum and Tanacetum vulgare (Asteracae) essential oils obtained by three methods of extraction. Journal of Economic Entomology 94: 167171.

De Montaigne, M., and Fall, A.M. 1986. La protection phytosanitaire des palmeraies en Mauritanie. Phytoma 9: 41-45.

Doumandji-Mitiche, B., and Doumandji, S. 1993. La lutte biologique contre les déprédateurs des cultures, Ed. O.P.U., Alger, Algérie, 94 pp.

Ganou, L. 1993. Contribution à l'étude de mécanismes fondamentaux de l'hydrodistillation des huiles essentielles, Thèse de doctorat $\mathrm{n}^{\circ} 689$, Institut National Polytechnique de Toulouse, France, 241 pp.
Guessoum, M. 1986. Approach of a bio-ecological study of the mite Oligonychus afrasiaticus (Boufaroua) on date palms. Annales de l'Institut Agronomique El Harrach, Algérie 10: $153-166$

Hay, R.K.M., and Waterman, P.G. 1993. Volatile oil crops. Wiley, Essex, United Kingdom, 185 pp.

Hussain, A.A. 1974. Dates palms and dates with their pests in Iraq. University of Baghdad, Iraq, $166 \mathrm{pp}$.

Idrissi Hassani, L.M., and El Hadek M. 1999. Analyse de la composition de l'huile de Peganum harmala L. (Zygophyllaceae). Acta Botanica Gallica 146: 353-359.

Idrissi Hassani, L.M., and Hermas, J. 2008. Effets de l'alimentation en Peganum harmala L. (Zygophyllaceae) sur le tube digestif du criquet pèlerin Schistocerca gregaria Forsk. (Orthoptera, Acrididae). Zoologica Baetica 19: 71-84.

Isman, M.B. 2000. Plant essential oils for pest and disease management. Crop protection 19: 603-608.

Isman, M.B. 2001. Pesticides based on plant essential oils for management of plant pests and diseases. Pages 1-9. In: Proceedings of International symposium on development of natural pesticides from forest resources. October 8-10, 2001, Forest Research Institute, Seoul, Republic of Korea.

Jovana, D., François, K., and Philippe, J. 2014. Les bio-pesticides, compléments et alternatives aux produits phytosanitaires chimiques. Biotechnology, Agronomy, Society and Environment 18: 220-232.

Júnior de Andrade, D., Martins da Rocha, C., Soares de Matos, S.T., and Zanardi, O.Z. 2020. Oxymatrine-based bioacaricide as a management tool against Oligonychus ilicis (McGregor) (Acari: Tetranychidae) in coffee, Crop Protection 134: 105182.

Kruskall, W.H., and Wallis, W.A. 1953. Use of ranks in one-criterion variance analysis. The Journal of the American Statistical Association 48: 907-911.

Martini, M.C., and Seiller, M. 1999. Actifs et additifs en cosmétologie. Procédés d'extraction des huiles essentielles. Editions Tec and Doc, Editions Médicales Internationales, France $563 \mathrm{pp}$.

Mastelic, J. 2001. The essential oil co-distillation by superheated vapour of organic solvents from aromatic plants. Flavour and Fragrance Journal 16: 370-373.

Peyron, L., and Richard H. 1992. L'extraction des épices et herbes aromatiques et les différents types d'extraits. Epices et aromates. Tec et 
Doc - Lavoisier, APRIA., Paris, France, 339 pp.

Piochon, M. 2008. Etude des huiles essentielles d'espèces végétales de la flore laurentienne: composition chimique, activités pharmacologiques et hémi-synthèse. Mémoire présenté à l'Université de Québec, Canada, 156 pp.

Qin, C.J. 1993. Properties and Analysis. Pages 54915501. In: Encyclopedia of Food Science, Food Technology and Nutrition. Academic Press, USA.

Rey, Ch., Carron, C. A., Cottagnoud, A., Bruttin B., and Carlen, Ch. 2004. La variété d'hysope officinale «Perlay». Revue Suisse de Viticulture, Arboriculture, Horticulture 36: 337-341.

Sankarikutty, B., and Narayanan, C.S. 1993. Isolation and Production. Pages 2185-2189. In:
Encyclopedia of Food Science, Food Technology and Nutrition. Academic Press, USA.

Singh, G., and Upadhyyay, R.K. 1993. Essential oils: a potent source of natural pesticides. Journal of Scientific and Industrial Research 52: 676683.

Starmans, D.A.J., and Nijhuis, 1996. Extraction of secondary metabolites from plant material: A review. Trends in Food Science and Technology 7:191-197.

Thakore, Y. 2006. The biopesticide market for global agriculture use. Industrial Biotechnology 2: 194-208.

Wang, L., and Weller, C. 2006. Recent advances in extraction of nutraceuticals from plants. Trends in Food Science and Technology 17: 300-312. 


\section{Plant Protection Events}

Announcing/Postponement

of

\section{The $13^{\text {th }}$ Arab Conference of Plant Protection}

Hammamet, Tunisia, 16-21 October, 2022
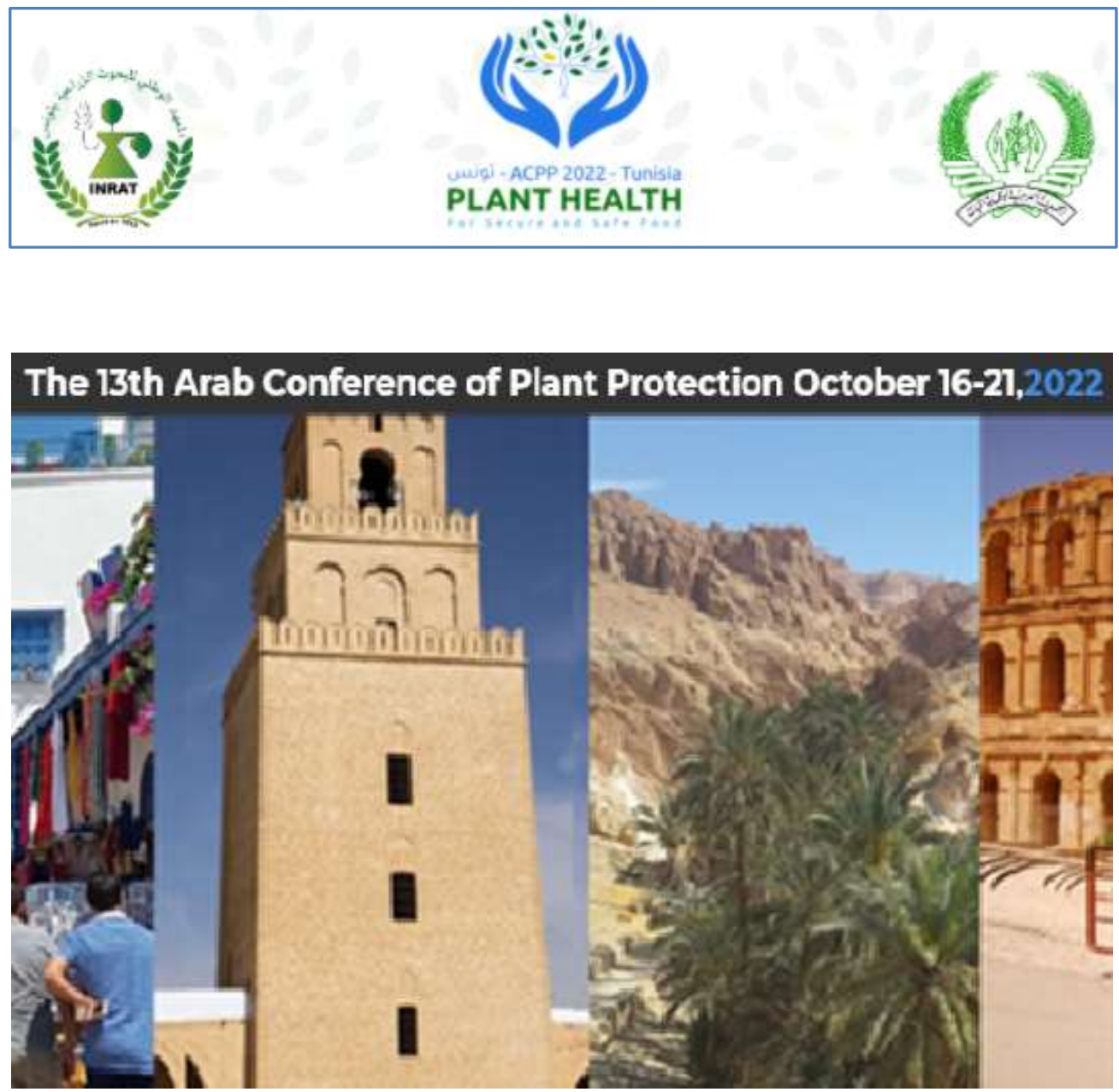


\section{Welcome to the 13th Arab Conference of Plant \\ Protection, Tunisia, 2022}

Dear Colleagues,

on behalf of the Arab society for Plant Protection and the Organizing Committee of the 13th Arab congress of Plant Protection, we invite you to participate in our coming congress to be held at the "Le Royal" Hotel, Hammamet, Tunisia, during the period October 16-21, 2022 with the general theme "Plant Health for a Secure and Safe Food". Excellent scientific presentations by Arab and Foreign speakers will be the backbone of our congress, in addition to one day agricultural and touristic tour to visit historical and cultural sites in Tunisia.

During five days, there will be plenty of opportunities for networking with colleagues during the symposia, concurrent oral and poster sessions or when visiting exhibition stands. In addition, social functions (welcome reception, morning and afternoon coffee breaks, lunch breaks and gala dinner) will be an appropriate occasion to interact informally with colleagues from different countries representing different institutions, public and private, who share common interests. Such interactions is a golden opportunity for initiating scientific exchange which can lead later to a formal or informal professional collaboration.

Looking forward to seeing you all in Tunisia in 2022, the year declared by the United Nations as the "Plant Health Year".
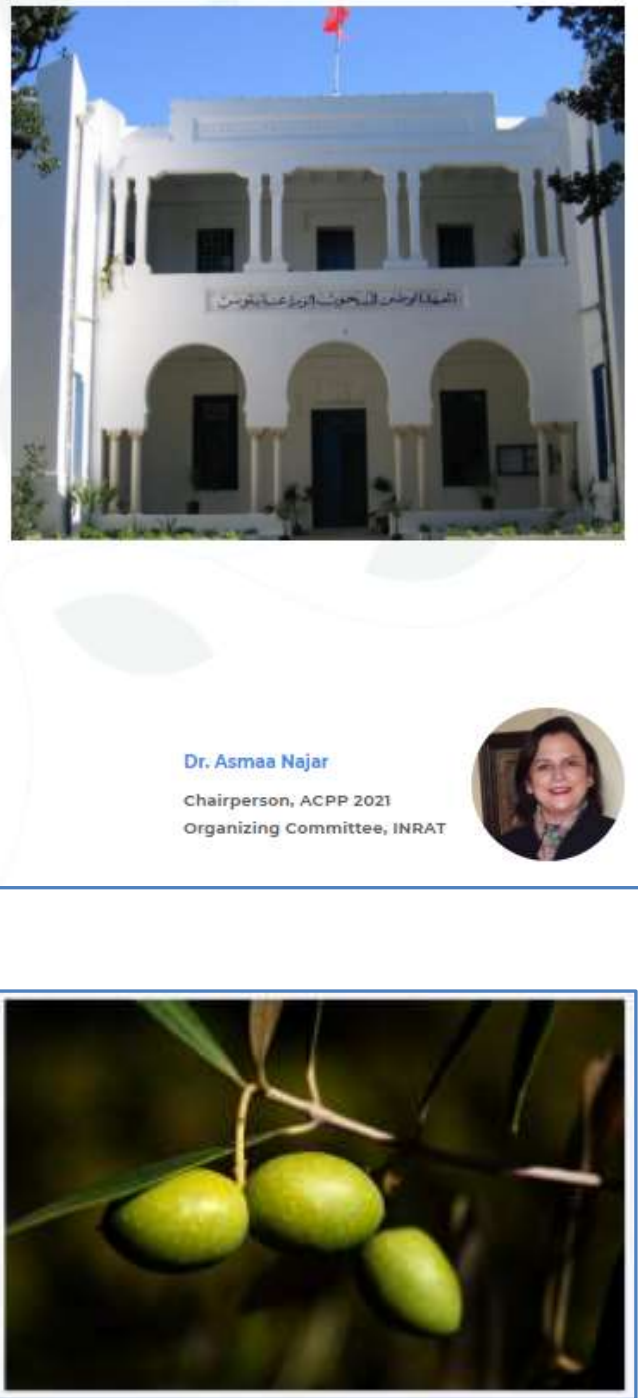


\section{Postponement of the 13th Arab Congress of Plant Protection}

Due to the continuation of the covid-19 pandemic and unstable health situation in Tunisia, the congress organizing committee decided to postpone the congress to october 2022. The society Executive Committee endorsed the new date and ensured getting the same hotel prices offered earlier.

1-The new congress date is october 16-21, 2022.

2-Registration deadline: September 1, 2022

3-Abstract's submission deadline (confirmation of earlier submitted abstracts or presenting new ones): April 30, 2022

4-Acceptance of abstracts: 30 June, 2022.

5-Deadline for submitting proposais for invited concurrent oral research papers sessions: March 31, 2022

6-Second congress announcement: May 31, 2022.

7-Third and final congress announcement: July 1, 2022

8-Deadline for hotel booking: July 31, 2022.

9-The email address and the website of the congress will continue to be: info @acpp-aspp.com and www-acpp-aspp.com

We apologize for any inconvenience caused by this postponement imposed on us by conditions beyond our control, and we appreciate your kind understanding. We are looking forward to meeting you all in the fall of 2022 in Tunisia.

The Arab Society for Plant Protection

The Organizing Committee of the $13^{\text {th }}$ Arab Congress of Plant

Protection in Tunisia

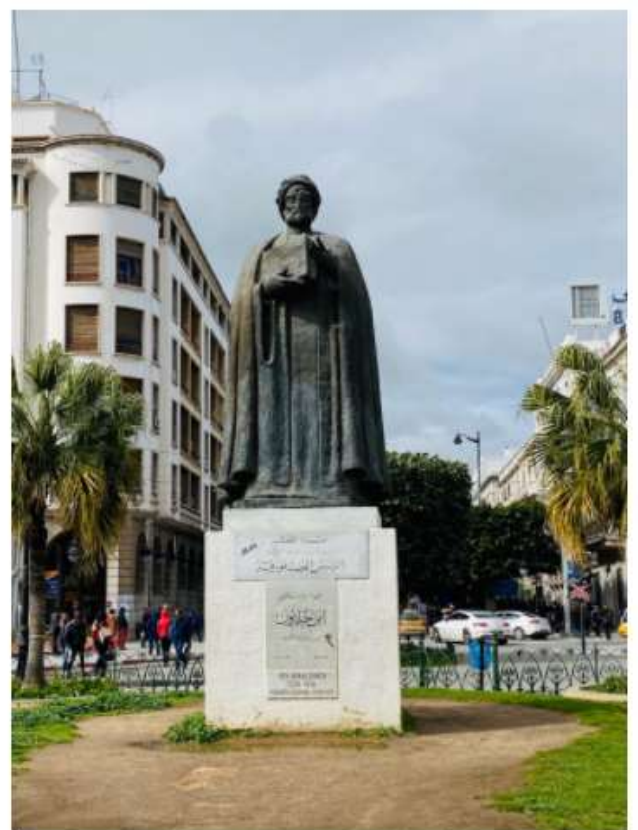




\section{TUNISIAN JOURNAL OF PLANT PROTECTION}

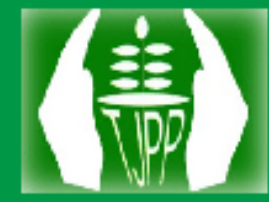

Vol. 16

No. 2

DECEMBER 2021

\section{CONTENTS}

\section{VIROLOGY}

19- Prevalence and genetic diversity of grapevine virus $D$ in Tunisia. Selmi, I., Elbeaino, T., Arezki, L., El Air, M., Digiaro, M., and Mahfoudhi, N. (Algeria/Italy/Tunisia) https//doi.org/10.52543/tjpp.16.2.1

\section{ENTOMOLOGY}

29- Evaluation under laboratory conditions of the efficacy of four extracts of spontaneous plants from the Mzab Valley (Algeria) against the date palm mite (Olgonychus ufrasiaticus). Babaz, Y., Guezoul, O., and Bouras, $N$. (Algeria)

https//doi.org/10.52543/tjpp.16.2.2

Photo of the cover page: Ofigonychus afrasiaticus (Courtesy Younes Babaz)

A Tunisian Half-Yearly Journal of Plant Healh Sciences (TJP) 